\title{
Operational malfunctions of turbochargers - reasons and consequences
}

\begin{abstract}
The paper discusses the most frequently occurring types of damage in turbochargers fitted in modern combustion engines and their influence on the engine basic operational indexes. The following causes of turbocharger malfunctions have been discussed: no lubrication, low lubricant pressure, reduced lubricant quality, foreign objects in the charged air and in the exhaust gas. Example malfunctions resulting from the said causes have been shown. The experimental part discusses the influence of a reduction of the charging pressure resulting from a leakage in the intake system on the effective parameters of a diesel engine fitted in light-duty and heavy-duty vehicles. The leakage in the intake system has been simulated by boring holes of the diameter of 3 and $12 \mathrm{~mm}$ in the intake manifold downstream of the turbocharger. The influence has been determined of the leakage of the turbocharging system on the value of the charging pressure, maximum effective power, engine torque, unit and hourly fuel consumption and the concentration of the exhaust components. A significant impact has been observed of the leakage of the turbocharging system on the effective parameters of the tested diesel engine and exhaust gas composition.
\end{abstract}

Key words: combustion engine, intake system, turbocharger, operational malfunctions

\section{Niesprawności eksploatacyjne turbosprężarek, ich przyczyny i skutki}

W artykule wskazano najczęściej występujące uszkodzenia turbosprężarek stosowanych we wspótczesnych silnikach spalinowych oraz przedstawiono ich wptyw na podstawowe wskaźniki operacyjne silników. Omówiono takie niesprawności turbosprężarek, jak: brak smarowania lub zbyt mate ciśnienie czynnika smarującego, jakość oleju smarującego, obecność ciał obcych w powietrzu i w spalinach. Przedstawiono przykładowe niesprawności spowodowane poszczególnymi czynnikami. W części doświadczalnej oceniono wpływ zmniejszenia ciśnienia doładowania spowodowanego nieszczelnościa uktadu dolotowego na parametry użyteczne silnika o zapłonie samoczynnym, stosowanego w samochodach dostawczych oraz osobowych. Nieszczelność układu dolotowego została zamodelowana przez wykonanie otworów o średnicy 3 i $12 \mathrm{~mm}$ w kolektorze dolotowym za turbosprężarka. Określono wpływ nieszczelności układu doładowania na wartość ciśnienia doładowania, maksymalna moc użyteczna, moment obrotowy silnika, jednostkowe i godzinowe zużycie paliwa oraz stężenie składników toksycznych $w$ spalinach. Stwierdzono istotny wpływ nieszczelności układu doładowania na parametry użyteczne $i$ sktad spalin silnika o zapłonie samoczynnym.

Słowa kluczowe: silnik spalinowy, układ dolotowy, turbosprężarka, niesprawności eksploatacyjne

\section{Introduction}

The operating conditions of turbochargers are characterized by: high pressure of the incoming exhaust gas, high speeds of the rotor reaching $120000-240000 \mathrm{rpm}$, high temperature of the propellant exhaust gas (on average, $800^{\circ} \mathrm{C}$ for diesel engines and $1000{ }^{\circ} \mathrm{C}$ for a spark ignition engines) acting on the turbine rotor and variable dynamic loads. An additional disadvantageous phenomenon influencing the operation of turbochargers is the pulsating pressure of the exhaust gas resulting from the firing order of individual cylinders [4].

For the said reasons the components of a turbocharger are subject to great mechanical and thermal stress. Turbocharger is, thus, an assembly extremely sensitive to any deviations from the designed conditions of operation. When designing turbochargers, the engineers constantly try to minimize their size, thus reducing the turbocharger rotating mass and its moment of inertia while increasing the effective range of turbocharger speeds. The main turbocharger components such as the rotors, shrouds, the shaft and slide bearings must be made from durable materials resistant to exhaust gas under arduous operating conditions.

\section{Wstęp}

Warunki pracy turbosprężarek charakteryzują: duże ciśnienie napływających spalin, duże prędkości obrotowe ich wirników wynoszące 120 000-240 $000 \mathrm{obr} / \mathrm{min}$ oraz wysoka temperatura napędzających spalin (średnio $800^{\circ} \mathrm{C}$ dla silnika ZS oraz $1000{ }^{\circ} \mathrm{C}$ dla ZI), działająca na wirnik turbiny, jak również zmienne obciążenia dynamiczne. Do niekorzystnych zjawisk wpływających na pracę turbosprężarek należą także pulsacje ciśnienia spalin w kolektorze wydechowym związane z kolejnością pracy poszczególnych cylindrów [4].

Ze wskazanych powodów elementy turbosprężarki poddane są dużym obciążeniom mechanicznym i cieplnym. Turbosprężarka jest więc zespołem bardzo czułym na wszelkie odstępstwa od przyjętych warunków eksploatacji. Przy konstruowaniu turbosprężarek dąży się do ciągłego minimalizowania ich gabarytów, co powoduje zmniejszenie mas wirujących i ich momentu bezwładności przy jednoczesnym zwiększeniu użytecznego zakresu prędkości obrotowych turbozespołu. Dlatego główne elementy turbosprężarki, tj. wirniki oraz kadłuby turbiny, sprężarki, wałek oraz łożyska ślizgowe, muszą być wykonane z materiałów, które w tych 
A properly operated and serviced turbocharger can work trouble-free for many years. Only external factors and improper operation and maintenance may be the cause of malfunctions or premature wear. Turbocharger malfunctions are most frequently caused by the following:

- no lubrication or insufficient lubrication pressure,

- poor lubricant quality,

- exceeded maximum speed of the rotating assembly,

- unbalanced turbine and compressor,

- contamination of air and exhaust gas,

- foreign objects in the intake air and in the exhaust gas,

- atmospheric corrosion,

- leakage in the intake manifold - upstream and downstream of the turbocharger,

- high exhaust gas temperature at the outlet of the turbine.

\section{No lubrication or insufficient lubrication pressure}

Insufficient lubrication of the turbocharger bearings may result from low lubricant feed pressure or low lubricant quality. This may be caused by a malfunction in the oil lubrication system as turbochargers and engine share the same system. High rotor speeds require constant lubrication with clean engine oil of appropriate quality and pressure. Properly fed engine oil, aside from its lubricating properties, also serves the purpose of a turbocharger coolant. The reason for an insufficient oil pressure may be blockage of the oil feed lines or malfunctioning turbocharger oil valve. Poor oil quality may be caused by its dilution with fuel or coolant. This leads to a loss of the lubricating properties, fading of the oil film and, eventually, premature wear of the turbocharger journal-bearing assembly. Excessively low lubricating pressure or its instantaneous lack contributes to the damage of the bearings (Fig. 1) and the turbocharger rotating assembly (Fig. 2).

The reason for excess wear of the resistance bearing may also be the reduced flow of exhaust gas through the exhaust system (clogged DPF or catalytic converter), which, again generates axial forces acting on the turbine rotor.

Excessive wear of the bearing and the shaft results in a greater play in this pair. It may be the cause of radial tilt which leads to scratching of the blades of the turbine/ compressor rotors against the shroud leading to their twist

a)

b)
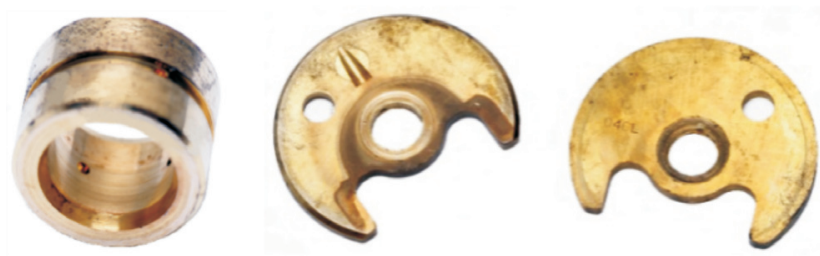

Fig. 1. Scratches caused by low quality and insufficient pressure of the lubricant or foreign objects in the lubricating oil: a) on the bearing race, b) on the resistance bearing [5]

Rys. 1. Zarysowania spowodowane zła jakościa i małym ciśnieniem oleju silnikowego lub ciałami obcymi w oleju: a) na bieżni łożyska wzdlużnego, b) na tożysku oporowym [5] trudnych warunkach zachowają dużą wytrzymałość i odporność na oddziaływujące spaliny.

Prawidłowo użytkowana i obsługiwana turbosprężarka jest zdolna do niezawodnej pracy przez wiele lat. Tylko czynniki pochodzące spoza turbosprężarki (z zewnątrz) oraz niewłaściwa eksploatacja mogą być przyczyną jej przedwczesnego zużycia lub awarii. Niesprawności turbosprężarek spowodowane są najczęściej następującymi przyczynami:

- brak smarowania lub zbyt małe ciśnienie czynnika smarującego,

- zła jakość oleju smarującego,

- niewyrównoważenie zespołu sprężarki i turbiny,

- zanieczyszczenia powietrza i spalin:

- obecność ciał obcych w powietrzu wlotowym i w spalinach,

- korozja atmosferyczna,

- nieszczelność układu zasilania powietrzem - przed i za turbosprężarką,

- wysoka temperatura spalin na wylocie z turbiny.

\section{Brak smarowania lub zbyt małe ciśnienie smarowania}

Niewystarczające smarowanie łożysk turbosprężarki może być spowodowane zbyt małym ciśnieniem dopływającego oleju lub jego złą jakością, co jest wynikiem niedomagania układu smarowania silnika, gdyż turbosprężarka smarowana jest olejem z tego układu. Duża prędkość obrotowa wirnika turbosprężarki wymaga stałego smarowania czystym olejem silnikowym o odpowiedniej jakości i właściwym ciśnieniu. Prawidłowo doprowadzony olej silnikowy poza właściwościami smarującymi pełni także funkcję chłodzenia turbosprężarki. Przyczyną niedostatecznego ciśnienia oleju może być niedrożność przewodów doprowadzających lub niewłaściwe działanie zaworu olejowego turbosprężarki. Zła jakość oleju może być spowodowana jego rozcieńczeniem przez paliwo lub płyn chłodniczy. Powoduje to utratę właściwości smarnych oleju, zanik filmu olejowego, a w efekcie przyspieszone zużycie skojarzenia czop-panewka wałka turbosprężarki. Zbyt małe ciśnienie smarowania lub chwilowy jego brak przyczyniają się do uszkodzenia łożysk (rys. 1) i zespołu wirującego turbosprężarki (rys. 2). a)

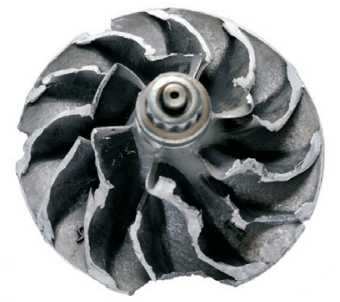

b)

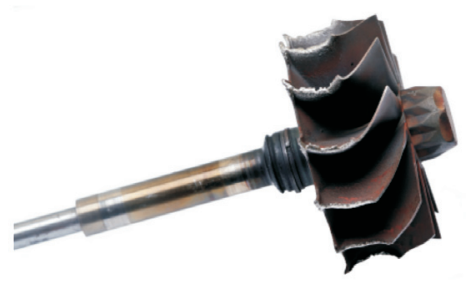

Fig. 2. Damaged air compressor wheel after hitting: a) the shroud, b) the iron housing caused by increased bearing play [5]

Rys. 2. Uszkodzone koło sprężarki powietrza po uderzeniu: a) o korpus sprężarki, b) topatek wirnika o żeliwna obudowę $w$ wyniku zwiększenia luzu ułożyskowania turbosprężarki [5] 
or breaking (Fig. 2a). Under extreme conditions a total seizure or breaking of the turbine/compressor rotor may occur (Fig. 2b).

A very sudden engine stop (before the engine speed is reduced and the temperature drops), particularly after operation at high loads, is detrimental for the life of a turbocharger. As at the moment of the engine stop, the compressor and the turbine are still rotating at high speeds (up to 240 thousand $\mathrm{rpm}$ ), the oil feed to the compressor bearings is inhibited as the lubrication comes under pressure from the operating engine. The oil film fades, which leads to a wear of the shaft and a continuous increase in the play of the bearings. This leads to a damage of the rotor seal and the oil begins to penetrate the engine intake system. a)

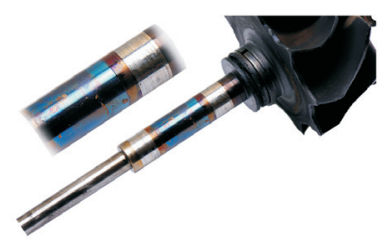

b)

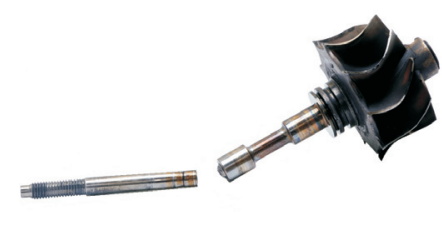

Fig. 3. Damage of the turbine rotor: a) surface overheat zone visible (purple-blue) caused by insufficient lubrication, b) breaking of the turbine rotor shaft caused by a seizure of the turbocharger bearings [5]

Rys. 3. Uszkodzenia wirnika turbiny: a) widoczna strefa przegrzania powierzchni (fioletowo-niebieski kolor) spowodowana niedostatecznym smarowaniem, b) pęknięcie watka wirnika turbiny spowodowane zatarciem łożysk turbosprężarki [5]

At the moment of sudden stop of the engine operating at high speeds and loads, the rotating assembly has a high temperature, which, with no lubrication of the shaft i.e. its chilling, leads to overheating (Fig. 3a) and burning of the residual oil.

Prolonged operation of the turbocharger with insufficient lubrication may lead to breaking of the turbine rotor shaft (Fig. 3b). This type of damage occurs when the bearings seize or the structure of the material changes following prolonged overheating.

\section{Quality of the lubricating oil}

The turbocharger shaft bearings are lubricated with the oil from the engine lubrication system. The quality of the lubricant is chiefly determined by the level of contaminants. The main engine oil contaminants are:

- mineral dust penetrating the oil by the air/fuel feed system,

- coolant getting through leakage in the lubrication system,

- fuel getting to the crankcase from the combustion chamber where it failed to burn due to injection system malfunction,

- remains of the wear of metal components of engine friction pairs,

- products of chemical transformation of the oil generated as a result of oxidation, thermal decomposition or polymerization of oil hydrocarbon compounds.
Przyczyną nadmiernego zużycia łożyska oporowego może być także przydławiony przepływ spalin przez układ wydechowy (np. niedrożny filtr cząstek stałych lub reaktor katalityczny), co z kolei prowadzi do powstania sił osiowych działających na wirnik turbiny.

Nadmierne zużycie łożysk i wałka to zwiększony luz w tym skojarzeniu. Może on być przyczyną odchylenia promieniowego wirnika, co w efekcie prowadzi do ocierania łopatek wirnika turbiny lub sprężarki o powierzchnię korpusu, a w następstwie tego do ich zużycia, wygięcia lub wyłamania (rys. 2a). W ekstremalnych warunkach może wystąpić całkowite zablokowanie lub pęknięcie wirnika sprężarki albo turbiny (rys. 2b).

Bardzo duże znaczenie dla pracy turbosprężarki, szczególnie gdy silnik pojazdu był eksploatowany z dużym obciążeniem, ma zbyt szybkie unieruchomienie silnika, zanim nastąpi zwolnienie obrotów turbosprężarki oraz częściowe obniżenie jej temperatury. W chwili unieruchomienia silnika sprężarka i turbina obracają się jeszcze z dużą prędkością (do 240 tys. obr/min), zanika dopływ oleju do łożysk turbosprężarki, gdyż są one smarowane pod ciśnieniem tylko podczas pracy silnika. Następuje zanik filmu olejowego, co powoduje zużycie wałka oraz systematyczne powiększanie luzu w łożyskach. Prowadzi to do uszkodzenia uszczelnienia wirnika i przedostawania się oleju do układu dolotowego silnika.

W chwili nagłego unieruchomienia silnika pracującego z dużą prędkością obrotową i pod dużym obciążeniem zespół wirujący ma wysoką temperaturę, co przy braku smarowania wałka, a tym samym jego chłodzenia, powoduje przegrzewanie (rys. 3a) i spalanie się oleju pozostałego w sprężarce.

Zbyt długa praca turbosprężarki z niedostatecznym smarowaniem może doprowadzić do pęknięcia wałka wirnika turbiny (rys. 3b). Tego typu uszkodzenie następuje w wyniku zatarcia łożysk lub zmian struktury materiału na skutek długotrwałego wpływu wysokiej temperatury.

\section{Jakość oleju smarującego}

Łożyska wałka turbosprężarki smarowane są olejem z układu smarowania silnika. O jakości oleju silnikowego w znacznym stopniu decydują zanieczyszczenia w nim zawarte. Głównymi zanieczyszczeniami oleju silnikowego są:

- pył mineralny przedostający się do oleju przez układ zasilania wraz z powietrzem i paliwem,

- płyn chłodzący dostający się przez nieszczelności układu smarowania,

- paliwo przedostające się do skrzyni korbowej z komory spalania, gdzie nie uległo spaleniu w wyniku niesprawności układu wtryskowego,

- produkty zużycia metalowych elementów skojarzeń współpracujących ciernie,

- produkty chemicznych przemian oleju powstałe w wyniku utleniania, rozkładu termicznego i polimeryzacji związków węglowodorowych oleju.

Zła jakość oleju może być wynikiem przedłużonego okresu wymiany oleju silnikowego, co skutkuje zwiększoną zawartością zanieczyszczeń, a w efekcie końcowym 
Poor oil quality may be a result of extended oil change intervals, which results in an increased amount of contaminants, and, eventually, premature friction-related wear of the turbocharger shaft and its bearings (Fig. 4).
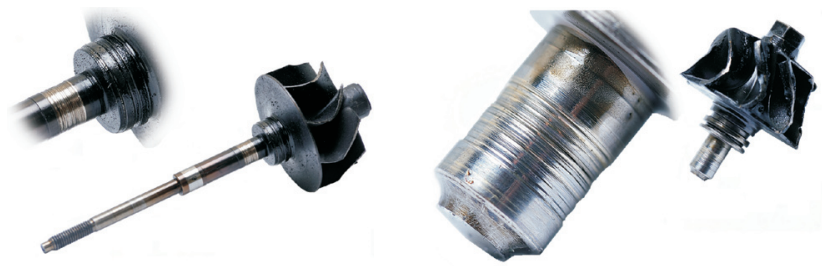

Fig. 4. Damage of the journal surface of the turbocharger shaft following lubrication with contaminated oil [5]

Rys. 4. Uszkodzenia powierzchni czopa wałka turbosprężarki w sytuacji smarowania nadmiernie zanieczyszczonym olejem [5]

A instant shutdown of an engine operating at high loads may lead to a situation when carbon deposits on the bearing. This leads to premature wear of the bearing surface and a reduced life of the turbocharger. Figure 5a shows a new bearing (1) and a used one (2) with visible traces of deposits.

One of the very frequently occurring malfunctions is the blockage of the line returning the oil from the turbocharger. If the oil cannot return, the lubrication and the cooling processes are disturbed and leakage may occur (Fig. 5b). Most often the oil begins to penetrate the turbocharger box or the shroud. Alternatively, the oil may remain in the turbocharger and, resulting from high temperatures carbon deposits will form on the turbine rotor, which may lead to a significant wear of the bearings, their housings and the turbine seal ring.

The oil, apart from its purpose of lubricating the friction pairs, also cools them. Insufficient oil pressure or its poor quality may lead to the turbocharger overheating, as a result of which the bearing will deform and scratch and the oil holes and grooves will be damaged. These malfunctions may lead to secondary damage such as:

- Seizure of the compressor and turbine rotors,

- Bending or breaking of the turbocharger shaft,

- Damage of the seals on the turbocharger shroud,

- Damage of the resistance or transverse bearings.

\section{Foreign objects in the air and exhaust gas}

Damage of the compressor or turbine rotors caused by foreign objects usually happens when foreign objects from the exhaust or intake systems get to the turbocharger (Fig. 6).

In most of the cases these are parts of the air cleaner case or the air filter element itself, parts of the fitting straps or if the engine itself fails - its consequences - fragments of valves, piston rings pistons, glow plugs or carbon deposits from the combustion chamber [3]. Following a hit of a foreign object on the blades of the turbine or the compressor they are usually mechanically damaged (deformation, breaking of one or several blades, scratching of the front part), which leads to unbalancing of the turbine and a reduction of the efficiency and service life of the turbocharger and eventually a serious damage. przyspieszonym ściernym zużyciem wałka i łożysk turbosprężarki (rys. 4).

Natychmiastowe wyłączanie obciążonego silnika może spowodować, że w łożysku będzie osadzać się nagar. Powoduje to przyspieszone zużycie powierzchni łożyska i skrócony okres użytkowania turbosprężarki. Na rysunku 5a pokazano łożysko nowe (1) i używane (2) z widocznymi śladami nagaru na powierzchni. a)

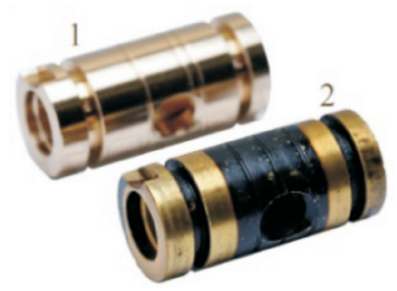

b)

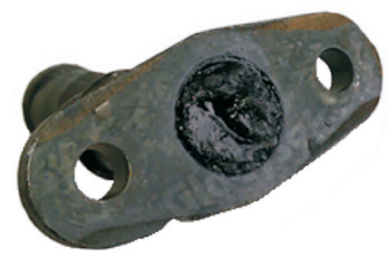

Fig. 5. Consequences of precipitation and influence of carbon deposits on the turbocharger components: a) deposition of carbon on the surface of the bearing, b) blockage of the oil return line from the turbocharger [5]

Rys. 5. Skutki wydzielania i oddzialywania nagaru na elementach turbosprężarki: a) osadzanie się nagaru na powierzchni łożyska wzdlużnego,

b) zatkanie nagarem przewodu splywu oleju z turbosprężarki [5]

Jedną z częstych awarii jest zablokowanie przewodu odprowadzającego olej z turbosprężarki. Brak możliwości spływu oleju przez zablokowany przewód (rys. 5b) uniemożliwia prawidłowe smarowanie i chłodzenie turbosprężarki oraz powoduje utratę jej szczelności. Najczęściej olej zaczyna wydostawać się do skrzyni wlotowej sprężarki lub do obudowy turbiny. W drugim przypadku istnieje ryzyko, że w wyniku działania wysokiej temperatury utworzy się nagar na powierzchni wirnika turbiny, który może spowodować znaczne zużycie łożysk, obudowy łożyskowań oraz pierścienia uszczelniającego turbiny.

Olej, poza smarowaniem współpracujących powierzchni dwóch elementów, ma również za zadanie ich chłodzenie. Niedostateczne ciśnienie oleju lub zła jego jakość mogą być przyczyną przegrzania turbosprężarki, w wyniku czego łożyska będą zdeformowane i porysowane, a otwory olejowe i rowki uszkodzone. Niesprawności te mogą powodować wtórne uszkodzenia, np.:

- zakleszczenie i uszkodzenie wirnika sprężarki lub turbiny,

- zgięcie lub pęknięcie wałka turbosprężarki,

- zniszczenie uszczelnień w obudowie,

- niszczenie łożysk oporowych i poprzecznych.

\section{Obecność ciał obcych w powietrzu i w spalinach}

Uszkodzenia wirnika sprężarki lub turbiny spowodowane przez obcy materiał występują najczęściej w wyniku przedostania się wraz z powietrzem do turbosprężarki elementów pochodzących z układu dolotowego lub wydechowego silnika (rys. 6).

W większości są to elementy obudowy filtra powietrza lub samego filtra, części opasek montażowych, a w przy- 
a)

b)
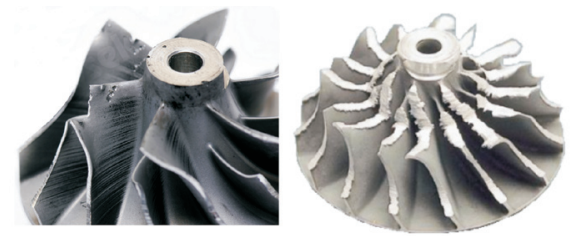

c)

Fig. 6. Damage of the rotor blade from the front side as a result of: a) a single hit of a foreign object [5], b) metal strap left in the intake system following an improper assembly [6], c) a foreign object present in the intake system

Rys. 6. Uszkodzenie łopatki wirnika sprężarki od strony czołowej wskutek: a) jednorazowego uderzenia niewielkim ciałem obcym [5], b) pozostawienia stalowej opaski montażowej w uktadzie dolotowym po nieprawidłowym montażu [6], c) dostania się do układu dolotowego ciała obcego

Damage of the turbine or the compressor rotor may also occur if the intake system is not airtight - cracked intercooler or leaking air feed lines. In such a case, contaminants (dust, salt etc.) may be sucked into the system. The contaminants in the exhaust gas (most often soot) are a frequent cause of malfunctions of the variable geometry system of the turbocharger. Following a deposition of contaminants, seizure and blockage of the variable geometry system occurs (Fig. 7).

Inaccurate control of the VGT blades results in surges of the charging pressure, hence improper turbocharger operation. A factor contributing to the formation of products of incomplete combustion is cold engine operation (coolant temperature $<70^{\circ} \mathrm{C}$ ). In extreme cases the variable geometry system seizes rendering the engine inoperative.

\section{Tightness of the charging system}

Tightness of the charging system is an important element that directly influences the operating parameters of a turbocharger. Loss of exhaust gas or air through the leakage leads to a drop in the charging pressure, which changes the engine operating parameters. Tests have been performed on a diesel engine - Renault G9T. This is a $\mathrm{V}_{\mathrm{ss}}=2.188 \mathrm{dm}^{3}$ Garett turbocharged engine commonly used in passenger and light-duty trucks. In the tests, the injectors, the turbocharger and the engine control unit were taken from a $66 \mathrm{~kW} / 3000 \mathrm{rpm}$ engine of maximum torque of $290 \mathrm{~N} \cdot \mathrm{m}$ at $1750 \mathrm{rpm}$.

The engine tests were performed on a typical engine dynamometer. The engine was loaded with a Schenck W 230 brake of the power of $230 \mathrm{~kW}$. The torque produced by the engine was measured by a tensometric converter. The engine speed was recorded using a pulse converter cooperating with a toothed wheel rim located at the brake coupling. For the measurement of the fuel consumption, AVL Fuel Balance was used that allowed sampling of the fuel consumption with the resolution of $5 \mathrm{~s}$. The airflow through the intercooler was generated by two fans. The temperature of the coolant was maintained on the level of $80-85^{\circ} \mathrm{C}$ using an external heat exchanger.

For the analysis of the exhaust gas components the authors used CEBII -2000 analyzers. It is fully automated, computer controlled measurement equipment. The shares of such exhaust components as nitrogen oxides $\mathrm{NO}$ and $\mathrm{NO}_{x}$ padku awarii silnika i jej następstw np. fragmenty zaworów, pierścieni, drobne części tłoków, świec żarowych lub nagar z komory spalania [3]. W wyniku uderzenia materiału obcego w łopatki sprężarki lub turbiny ulegają one najczęściej awarii w sposób mechaniczny (deformacja, oderwanie jednej lub kilku łopatek, starcie części czołowej sprężarki), co powoduje niewyrównoważenie turbiny, obniżenie sprawności i trwałości turbosprężarki, a w konsekwencji poważną awarię.

Uszkodzenia wirnika sprężarki lub turbiny mogą również powstać w sytuacji użytkowania pojazdów z nieszczelnym układem dolotowym, np. z pękniętą chłodnicą powietrza doładowującego „intercoolera” lub nieszczelnymi przewodami doprowadzającymi powietrze do silnika. Istnieje wtedy możliwość zassania do układu dolotowego zanieczyszczeń, takich jak pył, sól itp.

Znajdujące się w spalinach zanieczyszczenia, najczęściej sadza, są częstą przyczyną niesprawności układu sterowania napływem spalin na łopatki turbiny w sprężarkach ze zmienną geometrią. W wyniku osadzania się zanieczyszczeń następuje zatarcie i blokowanie mechanizmu sterującego wychyleniem łopatek kierownicy (rys. 7). a)
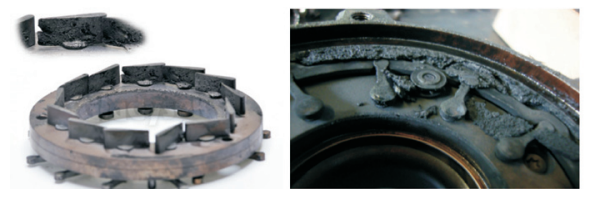

c)

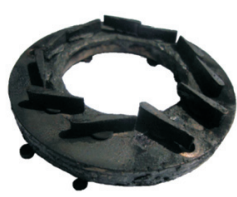

Fig. 7. Damage of the moving blades of the variable geometry system: a) a hit by a broken fragment of the turbine rotor blade [5], b, c) blockage caused by carbon deposit [7]

Rys. 7. Uszkodzenie ruchomych topatek kierownicy turbiny w wyniku: a) uderzenia przez oderwany fragment topatki wirnika turbiny [5], b, c) zablokowania przez nagromadzony nagar [7]

Nieprecyzyjne sterowanie kierownicami powoduje skoki ciśnienia doładowania, a tym samym niewłaściwą pracę sprężarki. Czynnikiem sprzyjającym powstawaniu produktów niezupełnego spalania jest praca silnika nierozgrzanego, czyli przy niskiej $\left(<70{ }^{\circ} \mathrm{C}\right)$ temperaturze czynnika chłodzącego. W skrajnych przypadkach dochodzi do zablokowania układu sterowania turbiny, co uniemożliwia użytkowanie pojazdu.

\section{Szczelność układu doładowania}

Szczelność układu doładowania jest ważnym elementem, który bezpośrednio wpływa na parametry pracy turbosprężarki. Ubytek spalin lub powietrza przez nieszczelności prowadzi do spadku ciśnienia doładowania, a w konsekwencji do zmian parametrów pracy silnika. Badania takie przeprowadzono na silniku ZS - Renault G9T. Jest to silnik o pojemności skokowej $\mathrm{V}_{\mathrm{ss}}=2,188 \mathrm{dm}^{3}$ doładowany turbosprężarką firmy Garett, powszechnie stosowany w samochodach osobowych i dostawczych.

$\mathrm{W}$ prezentowanych badaniach zastosowano układ zasilający (wtryskiwacze, turbosprężarka, sterownik silnika) od silnika pojazdu dostawczego, osiągającego moc maksy- 
were recorded using a vacuum chemiluminescent detector by EcoPhysics. The $\mathrm{CO}$ and $\mathrm{CO}_{2}$ analyzers operated based on the principle of absorbing infrared radiation and for the analysis of the hydrocarbons emission, flame ionization detector was used, whose principle of operation is based on burning of the hydrocarbons.

The results of the measurements of the engine parameters were stored during the entire experiment to ensure on-going control of the engine condition or to determine a possible malfunction and oversee the course of subsequent stages of the cycle. The results of the measurements of the effective engine parameters were reduced to normal conditions as per Polish standards PN-ISO 15550:2009.

Figures 8-12 show the influence of the reduced value of the charging pressure, resulting from the leakage, on the effective parameters of the Renault G9T engine. The leakage of the charging system was simulated by two holes of the diameter of 3 and $12 \mathrm{~mm}$ (the cross-section area was 7 and $112 \mathrm{~mm}^{2}$ respectively) located in the line between

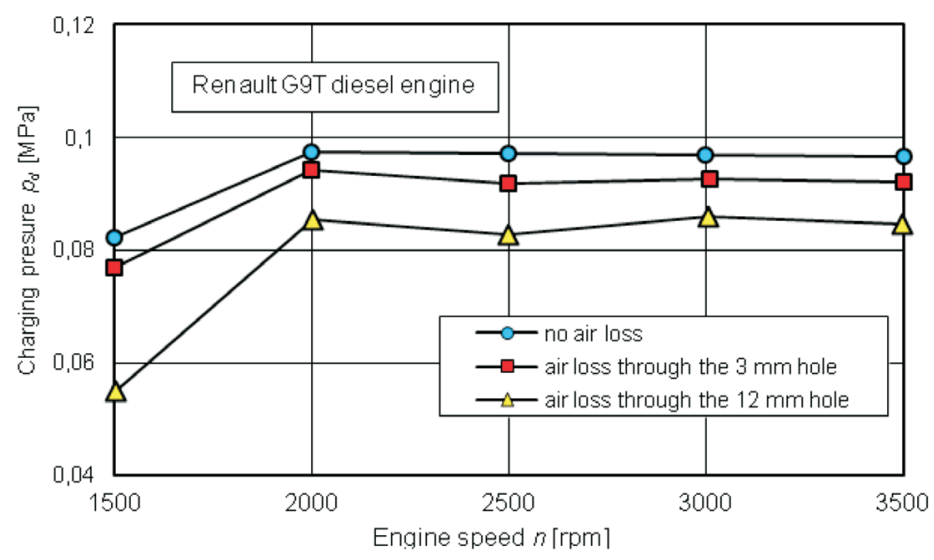

Fig. 8. The influence of the charging system leakage on the values of charging pressure $p_{d}$ of a Renault G9T diesel engine [1]

Rys. 8. Wplyw nieszczelności układu doładowania na wartość ciśnienia doładowania $p_{d}$ silnika ZS Renault G9T [1]

the turbocharger and the intercooler. The tests of the influence of each leakage on the full load engine characteristics were performed by developing a full load engine characteristics in the range of 1500-3500 rpm [1].

As the engine speed changes (Fig. 8) in the range 1500-2000 rpm a sudden increase in the charging pressure takes place. Above $n=2000 \mathrm{rpm}$ the charging pressure remains on a constant level and for a fully functional turbocharger has a value of $\mathrm{p}_{\mathrm{d}}=0.097 \mathrm{MPa}$.

Irrespective of the engine speed during the operation of the turbocharger with a leakage caused by a hole of the diameter of $3 \mathrm{~mm}$ in the first case and $12 \mathrm{~mm}$ in the second case, an almost parallel shift of the engine charging pressure characteristics $p_{d}=f(n)$ towards lower values occurs. A drop in the charging pressure of a turbocharger during operation with the malną $66 \mathrm{~kW}$ przy prędkości obrotowej $3000 \mathrm{obr} / \mathrm{min}$ oraz momencie $290 \mathrm{~N} \cdot \mathrm{m}$ przy $1750 \mathrm{obr} / \mathrm{min}$.

Badania silnika wykonano na typowym stanowisku dynamometrycznym. Silnik był obciążany hamulcem typu Schenck W 230 o maksymalnej mocy 230 kW. Moment obrotowy wytwarzany przez silnik był mierzony przy użyciu przetwornika tensometrycznego. Prędkość obrotową rejestrowano za pomocą przetwornika impulsowego, który współpracował z wieńcem zębatym umieszczonym na przyłączu hamulca. Do pomiaru zużycia paliwa wykorzystano wagę paliwową AVL FuelBalance, która umożliwiała próbkowanie zużycia paliwa co 5 s. Przepływ powietrza przez chłodnicę powietrza doładowującego wywołano, stosując zespół dwóch wentylatorów. Temperaturę płynu chłodzącego w silniku utrzymywano na poziomie $80-85{ }^{\circ} \mathrm{C}$ z wykorzystaniem zewnętrznego wymiennika ciepła.

Do analizy składników spalin zastosowano zestaw analizatorów spalin CEBII - 2000. Jest to w pełni zautomatyzowany, sterowany komputerowo zestaw przyrządów pomiarowych. Udziały takich składników spalin, jak tlenki azotu NO i NO był rejestrowany przy użyciu próżniowego detektora chemiluminescencyjnego analizatora firmy EcoPhysics. Analizatory $\mathrm{CO}$ i $\mathrm{CO}_{2}$ działały na zasadzie pochłaniania promieniowania podczerwonego, natomiast do rejestracji węglowodorów zastosowano analizator płomieniowo-jonizacyjny, którego zasada działania była oparta na spalaniu węglowodorów.

Wyniki pomiarów parametrów pracy silnika gromadzono w ciągu całego eksperymentu w celu bieżącej kontroli jego stanu technicznego lub określenia okoliczności ewentualnej awarii oraz kontroli przebiegu kolejnych faz cyklu badawczego. Wyniki pomiarów parametrów użytecznych silnika zredukowano do warunków normalnych zgodnie z normą PN-ISO 15550:2009.

Na rysunkach 8-12 pokazano wpływ zmniejszonej wartości ciśnienia doładowania, spowodowanej nieszczelnością układu doładowania, na parametry

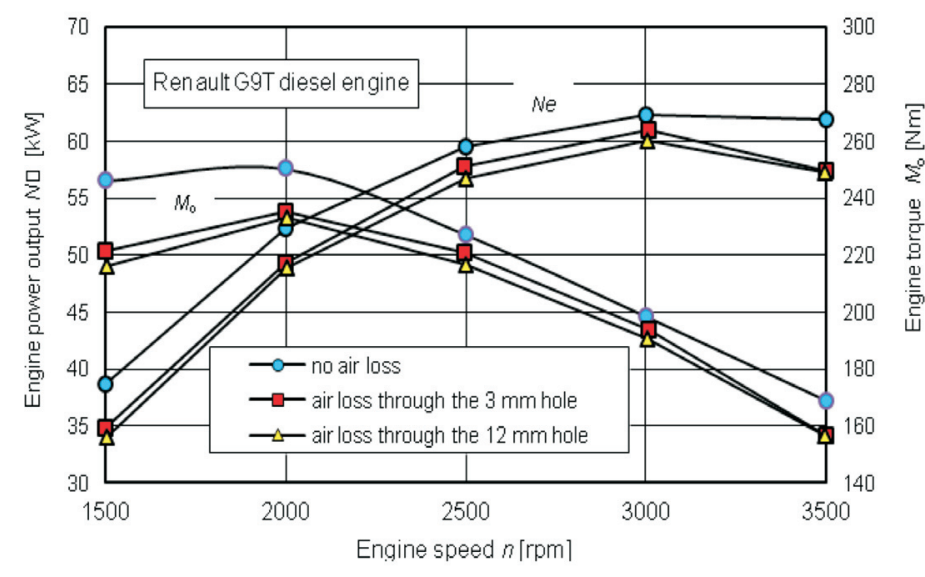

Fig. 9. The influence of the charging system leakage on power $\mathrm{N}_{e}$ and torque $\mathrm{M}_{\mathrm{o}}$ of the Renault G9T diesel engine [1]

Rys. 9. Wpływ nieszczelności układu doładowania na moc $N_{e}$ i moment $M_{o}$ silnika o ZS Renault G9T [1] 
$3 \mathrm{~mm}$ hole is $0.004 \mathrm{MPa}$ and the $12 \mathrm{~mm}$ hole $-0.014 \mathrm{MPa}$, as compared to a fully functional turbocharger.

From the full load characteristics of the Renault G9T engine it results that the greatest power $N_{e}$ and torque $M_{o}$ is produced by the engine when the charging system is airtight and fully functional, which confirms proper pairing of the engine and the turbocharger - Fig. 9.

A reduction of the charging pressure due to a leakage results in a drop of effective power in the entire range of engine speeds and torque with an almost parallel shift of characteristics $N_{e}=f(n)$ and $M_{o}=f(n)$ of the tested engine towards lower values.

A drop in the charging pressure by $0.004 \mathrm{MPa}$ (escape of air by the $3 \mathrm{~mm}$ hole) results in a decrease of maximum effective power by $3.7 \%$ and torque by $3.9 \%$. A further drop in the charging pressure following the escape of air through the $12 \mathrm{~mm}$ hole does not result in a significant drop of effective engine power and torque.

From the characteristics presented in Fig. 10 we know that the lowest unit fuel consumption is achieved by the engine when the turbocharger is fully functional. The loss of pressure through the leakage leads to an increased unit fuel consumption in the entire range of engine speeds and the most significant influence is seen when the engine speeds are extreme. The leakage in the charging system caused by the $3 \mathrm{~mm}$ hole at $\mathrm{n}=1500 \mathrm{rpm}$ leads to an increase in the fuel consumption by $13.6 \%$ as compared to a fully functional engine.

The influence of the charging system leakage (charging pressure) on the concentration of the exhaust components: nitrogen oxides $\left(\mathrm{NO}_{\mathrm{x}}\right)$, carbon monoxide $(\mathrm{CO})$ and hydrocarbons (HC) of the Renault G9T engine has been shown in Figures 11-13. The influence of the leakage on the concentration of $\mathrm{NO}_{\mathrm{x}}$ and $\mathrm{CO}$ is significant in the range of engine speeds $1500-2500 \mathrm{rpm}$. A reduction of the charging pressure by $0.014 \mathrm{MPa}$ (leakage caused by the $12 \mathrm{~mm}$ hole) results in a drop of the concentration of nitrogen oxides to the level of 550 ppm, i.e. $25 \%$. This is due to the specificity of $\mathrm{NO}_{x}$ formation whose maximum concentration in the exhaust gas occurs when the engine produces maximum power at high temperatures.

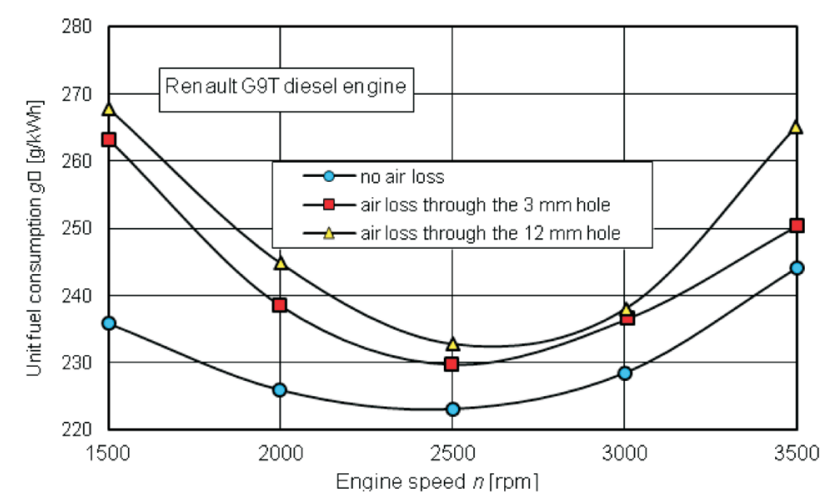

Fig. 10. The influence of the charging system leakage on specific fuel consumption $\mathrm{g}_{\mathrm{e}}$ of the Renault G9T engine [1]

Rys. 10. Wplyw nieszczelności układu doładowania na jednostkowe zużycie paliwa $g_{e}$ silnika Renault G9T [1] użyteczne silnika Renault G9T. Nieszczelność układu doładowania silnika zamodelowana została dwoma otworami o średnicy 3 i $12 \mathrm{~mm}$ (pole przekroju poprzecznego odpowiednio 7 i $112 \mathrm{~mm}^{2}$ ), znajdującymi się w przewodzie pomiędzy turbosprężarką a chłodnicą powietrza doładowującego, przez które następował ubytek powietrza doładowującego. Badania wpływu każdej nieszczelności na charakterystyki zewnętrzne silnika wykonano przez sporządzenie charakterystyki zewnętrznej silnika w zakresie prędkości obrotowych $1500-500 \mathrm{obr} / \mathrm{min}$ [1].

Wraz ze zmianą prędkości obrotowej silnika (rys. 8) w zakresie 1500-2000 obr/min następuje gwałtowny wzrost ciśnienia doładowania. Natomiast powyżej n $=2000 \mathrm{obr} / \mathrm{min}$ ciśnienie doładowania utrzymuje się na stałym poziomie i podczas pracy sprawnej (szczelnej) turbosprężarki ma wartość $\mathrm{p}_{\mathrm{d}}=0,097 \mathrm{MPa}$.

Niezależnie od prędkości obrotowej silnika, podczas pracy turbosprężarki z nieszczelnościami spowodowanymi w pierwszym przypadku otworem $3 \mathrm{~mm}$, a w drugim otworem o średnicy $12 \mathrm{~mm}$, następuje niemal równoległe przesunięcie charakterystyk ciśnienia doładowania $p_{d}=f(n)$ silnika w stronę mniejszych wartości. Spadek ciśnienia doładowania podczas pracy turbosprężarki z nieszczelnością w postaci otworu o średnicy $3 \mathrm{~mm}$ wynosi $0,004 \mathrm{MPa}$, a otworu o średnicy $12 \mathrm{~mm}-0,014 \mathrm{MPa} \mathrm{w}$ stosunku do ciśnienia doładowania sprężarki szczelnej.

Z charakterystyki zewnętrznej silnika Renault G9T wynika, że największą moc $\mathrm{N}_{\mathrm{e}}$ i moment $\mathrm{M}_{\mathrm{o}}$ uzyskuje silnik podczas pracy ze szczelnym układem doładowania, co świadczy o właściwym doborze sprężarki do silnika - rys. 9.

Zmniejszenie, w wyniku nieszczelności, ciśnienia doładowania powoduje w całym zakresie badanych prędkości obrotowych spadek mocy użytecznej, momentu obrotowego $\mathrm{z}$ jednoczesnym niemal równoległym przesunięciem charakterystyk $\mathrm{N}_{\mathrm{e}}=\mathrm{f}(\mathrm{n})$ i $\mathrm{M}_{\mathrm{o}}=\mathrm{f}(\mathrm{n})$ badanego silnika w stronę mniejszych wartości.

Spadek ciśnienia doładowania o 0,004 MPa (ucieczka powietrza przez otwór o średnicy $3 \mathrm{~mm}$ ) powoduje zmniejszenie maksymalnej mocy użytecznej o $3,7 \%$ i momentu

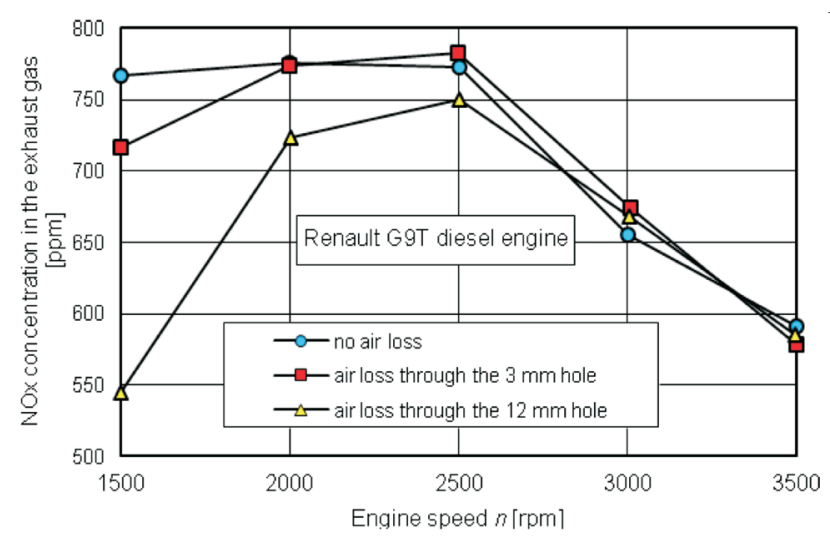

Fig. 11. The influence of the charging system leakage on the NO concentration in the exhaust gas of the Renault G9T engine [1]

Rys. 11. Wplyw nieszczelności układu doładowania na zawartość $N O_{x}$ w spalinach silnika Renault G9T [1] 


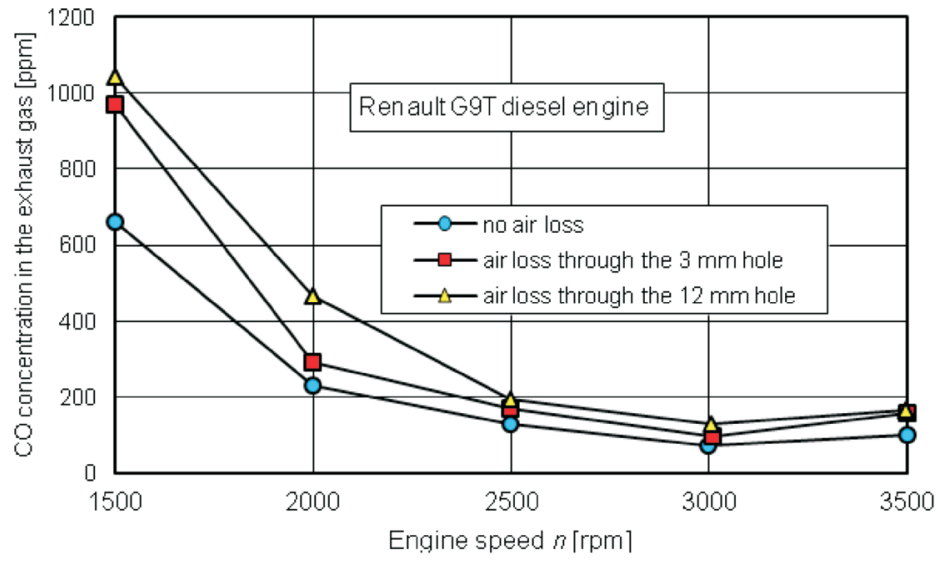

Fig. 12. The influence of the charging system leakage on the $\mathrm{CO}$ concentration in the exhaust gas of the Renault G9T engine [1]

Rys. 12. Wpływ nieszczelności układu doładowania na zawartość CO w spalinach silnika Renault G9T [1]

The leakage in the system results in a drop of the charging pressure and oxygen concentration in the cylinder charge, which is impactful on the $\mathrm{NO}_{\mathrm{x}}$ level in the exhaust gas. The concentration of $\mathrm{NO}_{x}$ at the engine speeds of $1500 \mathrm{rpm}$ is thus comparable with the concentration of $\mathrm{NO}_{x}$ at $3500 \mathrm{rpm}$.

The influence of the charging system leakage (charging pressure) on the concentration of $\mathrm{CO}$ in the exhaust gas of the Renault G9T engine has been shown in Fig. 12.

As the Renault G9T engine speed increases in the range $1500-2500 \mathrm{rpm}$ a sudden drop in the concentration of CO in the exhaust gas occurs (irrespective of the system airtightness). Above $n=2500 \mathrm{rpm}$ the concentration of $\mathrm{CO}$ in the exhaust gas remains on a steady (low - $100 \mathrm{ppm}$ ) level, whether or not there is leakage in the turbocharging system. As the air loss in the charging system increases, a significant increase in the concentration of carbon monoxide occurs in the engine speed range of 1500-2500 rpm. This phenomenon is particularly environmentally disadvantageous.

The concentration of hydrocarbons in the exhaust gas of the tested engine is miniscule and at the engine speed of maximum power $n_{N}=3000 \mathrm{rpm}$ it remains on the level

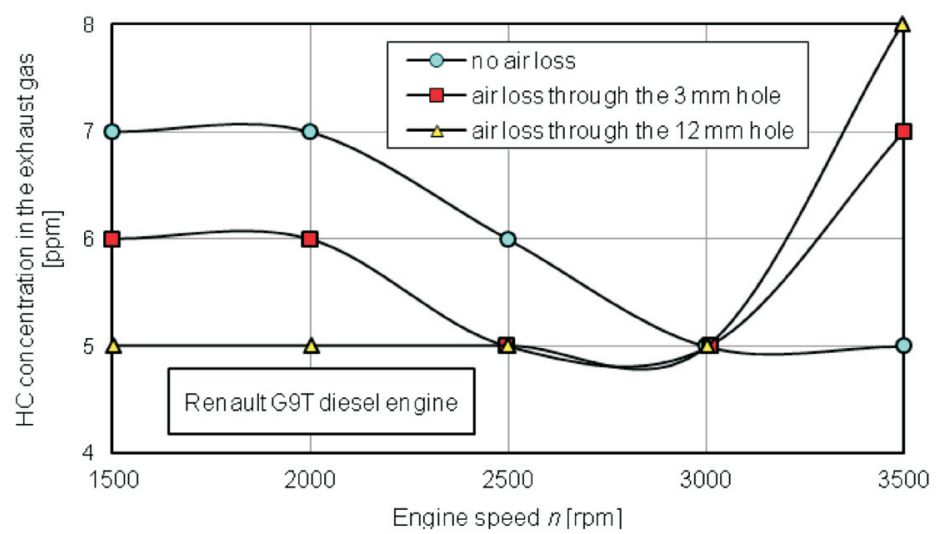

Fig. 13. The influence of the charging system leakage on the $\mathrm{HC}$ concentration in the exhaust gas of the Renault G9T engine [1]

Rys. 13. Wpływ nieszczelności układu doładowania na zawartość HC w spalinach silnika Renault G9T [1] maksymalnego o 3,9\%. Dalszy spadek ciśnienia doładowania w wyniku wypływu powietrza przez otwór $12 \mathrm{~mm}$ nie powoduje istotnego spadku mocy użytecznej i momentu obrotowego silnika.

$\mathrm{Z}$ przedstawionych na rysunku 10 charakterystyk wynika, że najmniejsze jednostkowe zużycie paliwa badany silnik osiąga podczas pracy turbosprężarki szczelnej. Ubytek powietrza przez nieszczelności powoduje zwiększenie jednostkowego zużycia paliwa w całym zakresie prędkości obrotowej silnika, największy jego wpływ zaznacza się podczas pracy silnika przy skrajnych prędkościach obrotowych. Nieszczelność układu doładowującego spowodowana otworem o średnicy $3 \mathrm{~mm}$ powoduje przy prędkości $\mathrm{n}=1500 \mathrm{obr} / \mathrm{min}$ zwię)kszenie jednostkowego zużycia paliwa o $13,6 \% \mathrm{w}$ stosunku do silnika w pełni sprawnego.

Wpływ nieszczelności układu doładowania (ciśnienia doładowania) na stężenie toksycznych składników spalin: tlenków azotu $\left(\mathrm{NO}_{x}\right)$, tlenku węgla (CO) oraz węglowodorów (HC) silnika Renault G9T pokazano na rys. 11-13. Wpływ nieszczelności na stężenie $\mathrm{NO}_{\mathrm{x}}$ i CO jest znaczny

W zakresie prędkości obrotowej 1500-2500 obr/min. Zmniejszenie ciśnienia doładowania o 0,014 MPa (nieszczelność spowodowana otworem o średnicy $12 \mathrm{~mm}$ ) powoduje spadek zawartości tlenków azotu do poziomu 550 ppm, a więc o $25 \%$. Wynika to ze zjawiska tworzenia się NO, których maksymalne stężenie w spalinach występuje podczas pracy silnika w obszarze mocy maksymalnej i w wysokiej temperaturze.

Nieszczelność układu spowodowała spadek ciśnienia doładowania i zawartości tlenu w dostarczonym do cylindrów ładunku, co wpłynęło na zmniejszenie zawartości $\mathrm{NO}_{\mathrm{x}}$. Tym samym zawartość NO przy prędkości obrotowej 1500 obr/min jest porównywalna $\mathrm{z}$ zawartością tlenków azotu przy $3500 \mathrm{obr} / \mathrm{min}$.

Wpływ nieszczelności układu doładowania (ciśnienia doładowania) na stężenie CO w spalinach silnika Renault G9T przedstawiono na rys. 12 .

Wraz ze wzrostem prędkości obrotowej silnika Renault G9T w zakresie 1500-2500 obr/min następuje (niezależnie od szczelności układu) gwałtowne zmniejszenie zawartości CO w spalinach. Natomiast powyżej $\mathrm{n}=2500 \mathrm{obr} / \mathrm{min}$ zawartość $\mathrm{CO}$ w spalinach utrzymuje się na stałym, niskim (około 100 ppm) poziomie, niezależnie czy silnik doładowywany jest turbosprężarką z nieszczelnością, czy też nie. Wraz ze wzrostem ubytku powietrza z układu doładowującego następuje znaczny wzrost zawartości tlenku węgla w spalinach w zakresie 1500-2500 obr/min. Jest to zjawisko szczególnie niekorzystne ze względu na ochronę środowiska.

Zawartość węglowodorów w spalinach badanego silnika jest nieznaczna i przy prędkości obrotowej mocy maksymalnej $n_{\mathrm{N}}=3000 \mathrm{obr} /$ min utrzymuje się na poziomie około 5 ppm niezależnie od nieszczel- 
of approx. 5 ppm whether or not the system has a leakage (Fig. 13). If the system is airtight, the concentration of $\mathrm{HC}$ in the exhaust gas decreases in the entire range of engine speeds. A disadvantageous influence of the leakage on the $\mathrm{HC}$ concentration becomes visible when the engine exceeds the speed of maximum power $n_{N}=3000 \mathrm{rpm}$. The concentration of $\mathrm{HC}$ in the exhaust gas increases to $8 \mathrm{ppm}$ with the leakage caused by the $12 \mathrm{~mm}$ hole.

\section{Conclusions}

The analysis of the literature and obtained research results allowed formulating the following conclusions:

1. The service life of a properly operated and maintained turbocharger can be very long. Only improper operation and maintenance me be the reason for premature wear or malfunctions. The efficiency of the turbocharger system of a diesel engine is decisive of the efficiency of the entire engine including its performance.

2. The loss of air from the charging system is a very disadvantageous phenomenon in terms of the operating parameters: reduced engine power, increased unit fuel consumption, increased exhaust emissions and reduction engine flexibility.

3. The loss of air from the charging system leads to an increase in the temperature of combustion, which leads to increased thermal loads of the piston-crankshaft assembly. This may lead to a reduced life of the mating parts.

4. It appears purposeful to continue research aiming at determination of the influence of the intake system leakage on the EURO emission standard compliance during reproduction of the unified driving cycle. ności układu doładowującego (rys. 13). Przy szczelnym układzie doładowującym zawartość HC w spalinach maleje w całym zakresie prędkości obrotowej. Niekorzystny wpływ nieszczelności na stężenie HC zaznacza się po przekroczeniu przez silnik prędkości obrotowej mocy maksymalnej $\mathrm{n}_{\mathrm{N}}=3000 \mathrm{obr} / \mathrm{min}$. Zawartość HC w spalinach wzrasta do 8 ppm przy nieszczelności spowodowanej upustem powietrza przez otwór $12 \mathrm{~mm}$.

\section{Wnioski}

Przeprowadzona analiza literatury i uzyskanych wyników badań pozwoliła na sformułowanie następujących wniosków:

1. Prawidłowo użytkowana i obsługiwana turbosprężarka jest zdolna do niezawodnej pracy przez wiele lat. Tylko niewłaściwa eksploatacja może być przyczyną jej przedwczesnego zużycia lub awarii. Sprawność układu doładowania silnika ZS w dużym stopniu decyduje o sprawności całego silnika i jego osiągach.

2. Ubytek powietrza z układu doładowania jest zjawiskiem bardzo niekorzystnym ze względu na obniżenie parametrów użytecznych silnika: spadek mocy, zwiększenie jednostkowego zużycia paliwa, wzrost stężenia składników toksycznych w spalinach oraz zmniejszenie elastyczności silnika.

3. Ubytek powietrza z układu doładowania powoduje zwiększenie temperatury spalania, co w efekcie prowadzi do zwiększenia obciążeń cieplnych elementów układu tłokowo-korbowego silnika, co może mieć wpływ na zmniejszenia jego trwałości.

4. Celowe wydaje się wykonanie dalszych badań mających na celu określenie wpływu nieszczelności układu dolotowego na spełnienie wymagań zawartych w normach EURO podczas odtwarzania zunifikowanego cyklu jezdnego.

\section{Bibliography/Literatura}

[1] Adamczuk M., Ocena wpływu ciśnienia doładowania na osiągi silnika o zapłonie samoczynnym (ZS), praca dyplomowa. WAT, Warszawa 2013.

[2] Dziubak T., Szwedkowicz S. Experimental research on filtering fibers in a cyclone-porous barrier system, Combustion Engines, No. 3/2014 (158)

[3] Dziubak T. Filtracja powietrza wlotowego do silników spalinowych pojazdów mechanicznych. WAT, Warszawa 2012.

[4] Mysłowski J. Doładowanie silników. WKŁ, Warszawa 2011.
[5] www.naprawa-turbosprezarek.pl/turbosprezarki_uszkodzenia_usterki_turbin.html. [data dostępu: 12.08.2015].

[6] www.zssplus.pl/publikacje/publikacje49.htm. [Data dostępu: 25.08.2015].

[7] www.turbo-pro.pl/pl/przyczyny-awarii.html. [Data dostępu: 28.09.2015.]

[8] PN-ISO 15550:2009 - Silniki spalinowe tłokowe. Określanie i metoda pomiaru mocy silnika - Wymagania ogólne.
Tadeusz Dziubak, DSc., DEng. - Professor at the Faculty of Mechanics Military University of Technology, Warsaw, Poland.

Dr hab. inż. Tadeusz Dziubak-profesor na Wydziale Mechanicznym Wojskowej Akademii Technicznej w Warszawie.

e-mail:tadeusz.dziubak@wat.edu.pl

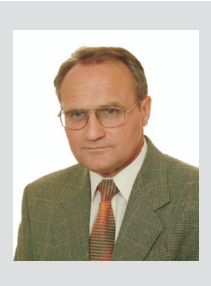

Miroslaw Karczewski, DEng. - doctor at the Faculty of Mechanics Military University of Technology, Warsaw, Poland.

Dr inż. Miroslaw Karczewski-adiunkt na Wydziale Mechanicznym Wojskowej Akademii Technicznej $w$ Warszawie.

e-mail: miroslaw.karczewski@wat.edu.pl 